\title{
Starting from the end: a plea for focusing on the consequences of crime
}

\author{
Letizia Paoli and Victoria A. Greenfield
}

Postprint of article published in the European Journal of Crime, Criminal Law and Criminal Justice 23 (2015) 87-100

Since its institutionalization as an autonomous discipline in the late 19th century, criminology's main project has been identifying the causes of crime. The project began when Cesare Lombroso, the "father" of criminology, applied the methods of the natural sciences to explain why some individuals commit crime (e.g., Fijnaut, 2014). Building on L'Uomo Delinquente (Lombroso, 1876), the ensuing literature has greatly enhanced our understanding of the problem of crime, its causes, and its links to the broader societal context (e.g., Merton, 1938; Hirschi, 1969; Sampson, 2013; Wikstrom et. 2013). Nonetheless, it is fair to say that the "Lombrosian project" (Garland, 2002) remains unfulfilled. A quick skim of any criminological handbook aptly demonstrates a lack of consensus on the causes of crime (e.g., Newburn, 2007; Cullen, Agnew and Wilcox, 2013 and Fijnaut, 2014).

Nearly 100 years after Lombroso, the traditional positivist, etiological approach to crime was challenged "from the left and the right" (Laub, 2004: 8; see also Cohen, 1988 and Bottoms, 2008). During the 1960s, symbolic interactionists and labelling theorists dismissed causality and focused on the social construction of deviance and crime, showing that the concept of crime is far from being a stable and natural explanandum as in the natural sciences. Building on this movement, critical criminologists in the 1970s re-emphasized the normative dimension of criminological research, rightly claiming that criminological research is itself part of the political process.

From the mid-1970s onward, a varied group of so-called "neo-classical" or "administrative" criminologists turned its attention to the crime event, arguing that the search for the root causes of crime is irrelevant to policy. They developed opportunity theories and the field of situational crime prevention (e.g., Mayhew et al., 1976; Cohen and Felson, 1979; Sherman, Gartin and Buerger, 1989). This second challenge to the traditional approach was sufficiently dramatic to inspire Ron Clarke (2004) to propose "crime science" as an alternative to criminology. As a new applied discipline, it would focus on the "how" rather than on the "why" of crime and aim to reduce crime in the here-and-now rather than engender long-term social reform.

Both these new streams of reflection and research have greatly improved our understanding of crime problems and their social construction and the way we deal with both. At the same time, they have enriched the scientific debate within criminology and contributed to the policy relevance of criminology. 
In this editorial, we argue that it is time to go a step further; namely, to "start at the end" and expand the discipline, by making the empirical, systematic assessment of the consequences of crime a new branch of criminology. We believe that giving those consequences and, more specifically, the harms of crime, a place of prominence in criminology would benefit both the discipline and crime-control policy. First, it would allow criminology to better address the criticisms raised "from the left and the right" (Laub, 2004: 8). Second, it could provide crucial evidence for establishing policy priorities, making policy more cost effective, and improving the accountability of policy. In addition, we will argue that harm has a place not just in the formulation of responses to criminal activities, but also in the designation of particular activities as "criminal" offences. Before developing these arguments, we summarily review the state-of-the-art in research and applications and consider the reasons for the underdevelopment of "harm" in both criminology and crime control.

\section{The State-of-the-Art in Research and Applications}

Paoli and Greenfield (2013) provide a review of the literature on harms and related concepts, including the perceived seriousness of crime, the cost of crime, and the impact of criminal victimization. While we refer the reader to that article for a detailed and critical discussion, and draw heavily from it here, we stress here that we are not starting from a tabula rasa-either in criminology or the larger policy debate.

Since the 1970s, concern has risen on both sides of the Atlantic about the individuals who are harmed by crime, as evidenced by the extensive media coverage of victims and their experiences and the wide range of victim initiatives and legislation.

Reflecting these cultural and policy changes, victimology has expanded significantly (e.g., Walklate, 2007 and Shoham, Knepper and Kett, 2010).

Largely independent of that development, other scholars (e.g., Clear, 1995; Rubin, 1999 and Sherman, 2007) have recommended making the minimization of the total harms of crime and control policies the main goal of crime control and even social policies (Sparrow, 2008). Some critical criminologists (e.g., Hillyard and Tombs, 2004) have offered up a yet more-radical paradigm shift and gone as far as to propose replacing the notion of crime with that of social harm and making the reduction of social harm the key goal of broader social policy (see also Yar, 2012). Other criminologists have applied the concept of harm to state crimes, to mass atrocities, and to a variety of environmentally detrimental and inhumane activities, not all of which are "criminal" (e.g., Rothe, and Kauzlarich, 2014 and White, 2011).

Numerous studies have also examined the growth of the prison industry since the 1970s in the United States and elsewhere (e.g., Christie, 2000) and have shown the dysfunctional and criminogenic effects of imprisonment (e.g., Clear, 2007 and Waquant, 2009). This body of literature has contributed to initial, if tentative attempts to reduce mass imprisonment in the US.

At the same time, policy-making and law enforcement agencies have expressed interest in harm as a guiding construct. For example, several national (see SOCA, 2008 
and Tusikov, 2012) and regional (e.g., Europol, 2013) agencies and the EU as a whole (e.g., TFEU, 2008 and European Council, 2010) have called for law enforcement to prioritize and target criminal activities, particularly those considered typical of organized crime, on the basis of their harmfulness.

In the realm of drug policy, several European countries have built harm-reduction programs into their national drug control strategies (e.g., EMCDDA, 2012) and calls for supply-oriented applications of harm reduction principles are intensifying in Europe and elsewhere (e.g., Caulkins and Reuter, 1997; UK Drug Policy Commission 2009; Greenfield and Paoli, 2012).

Despite these policy and scientific developments, the empirical, systematic assessment of the consequences and specifically the harms of crime has long remained a "blind spot" within criminology and the public debate on crime control. Very few scholarly advocates of harm-based approaches to crime-control policy have developed rigorous typologies or assessment tools. Rubin (1999) provides an entry point for serious consideration of harm, but offers no specification; Hillyard and Tombs (2004) suggest the scope of a social harm approach, but only briefly. Sherman (2007) and Sherman et al. (2014) first proposed and then created a "total harm index," but do not distinguish the harms of crime from the perceptions of the public or policy makers. Kopp and Besson (2009), Levi and Burrows (2008), Levi et al. (2013), and others de facto equate harm with social cost and, following the cost-of-crime literature, include the costs of societal reactions. Paoli and Greenfield (2013) could find only three scholarly attempts to categorize the harms of crime-those of Maltz (1990), von Hirsch and Jareborg (1991), and Dorn and van de Bunt (2010). With few exceptions (Maltz, 1990; Clarkson et al., 1994 and Shepherd, 1997), these attempts have not been put to use in empirical assessments.

In recent years, several government agencies have endeavored to report on the harms of organized crime and to develop methodologies to assess the harms of organized and other crime, more generally (Europol, 2013; see Tusikov, 2012 for a review). While they represent advancement, these methods either have conceptual or technical weaknesses or they are based on criminal law sentences or sentencing guidelines and, thus, cannot provide an independent basis for establishing policy priorities or criminality. In other cases, such as Europol's, which now must identify the crimes to be prioritized in the EU's multi-year program on serious and international organized crime, the methodology has not been published in detail and does not distinguish between the harms directly caused by a criminal activity and those resulting from the criminalization of such activities and specific policy interventions (Paoli, 2014).

In a recent article, we (Greenfield and Paoli, 2013) have developed a harm assessment framework, drawing from von Hirsch and Jareborg's living standard approach and borrowing insights from the literatures of the drug policy community (e.g., MacCoun Reuter and Schelling, 1996, and Newcombe, 1992) and, less predictably, the national security community (e.g., Greenfield and Camm, 2005). The 
framework, which weaves together a set of descriptive and analytic tools in a multistep process of application, evaluation, and prioritization, allows users to:

- Characterize the modus operandi of the activity in a "business model."

- Identify the possible harms associated with the activity, using a taxonomy that distinguishes among different types of harm and bearers, including individuals, government and private-sector entities, and the environment.

- Evaluate the severity and incidence of actual harms, using quantitative and qualitative evidence from official records, interviews, press reports, and other sources, on the basis of two ordinal scales.

- Prioritize harms, by using a relational matrix to combine the scales.

- Establish the causes of the harms, first, by distinguishing the harms directly resulting from a criminal activity from those that are "remote" and, second, by examining the extent to which the harms associated with a criminal activity arise from the policy environment and related practices.

With other scholars, we have tested the framework on drug production, drug trafficking, and human trafficking in Belgium and the Netherlands (vander Beken et al., 2012; Paoli, Greenfield and Zoutendijk, 2013; Paoli and Kersten, 2013 and Paoli, Decorte and Kersten, 2015) and shown that it can produce reliable, multi-faceted, and policy-relevant harm "estimates." We have also received expressions of interest in applications to broader ranging crimes from policy communities in Australia, New Zealand, and the UK and at the EU level.

Interestingly, harm has had, starting with John Mill's "harm principle," ([1859] 1977) a greater place in legal theory than in criminology. Most legal scholars would agree that the real or purported harm constitutes $a$, if not the, reason why most actions we now call "crimes" have been criminalized in the first place (Eser, 1966; Clear, 1994 and Ashworth, 2006). Albeit in most cases only implicitly, the penal codes and sentencing policy of contemporary societies reflect the (perceived) seriousness of the offences, for example by establishing maximum sentences or regarding sentences that were grossly excessive in relation to the gravity of the offence as unfair. Since the 1970s, efforts to reform sentencing and sentencing guidelines in Finland, Sweden, and, later, the UK have, under the influence of the so-called "just desert" or "retributivist" theories, explicitly required the severity of the penalty to be proportionate to the seriousness of the offence (von Hirsch, 2009).

However, neither the legal theorists discussing proportionate sentences nor the policy-makers drafting penal codes or sentencing guidelines have engaged in the empirical assessment of the harms of different criminal activities. Because of this, retributivist theories are plagued by what Lippke (2012: 464) defines as "one of the unsolved, and seemingly insoluble, problems of sentencing theory"; namely, the lack of "anchoring points" of a sentencing scheme. 


\section{Possible Reasons for the Underdevelopment of Harm}

Notwithstanding the growing interest in "harm" as an evidence-based approach to crime-control policy, our past explorations of the literature (Paoli and Greenfield, 2013) suggest that criminologists and policy makers have oftentimes viewed crime as a "harm" in its own right and, thus, until very recently made few practical attempts to assess the harms of different criminal activities as distinct from the perceived seriousness or costs of crime. Moreover, both communities have tended to focus on a small set of mala in se offence, such as murder and theft, neglecting the thousands of crimes that one might consider mala prohibita, ranging from drug trafficking to regulatory offences. It is always hard to know why people abstain from doing things, but here we posit reasons, albeit speculative, for the underdevelopment of "harm" in academia and policy.

In both communities, a combination of historical entrenchment and "philosophical" factors might have played a part in the underdevelopment, but not without support from other more-pragmatic considerations.

As for criminologists, etiology has long been in the mainstream and considered by many as the only truly "scientific" lens with which to study crime; hence, there has been a persistent focus on the causes, with little inclination for the empirical, systematic assessment of the consequences of crime (Wikstrom, 2008). But, in fairness to academia, daunting conceptual and technical challenges likely have dampened interest in "harm" as an alternative lens. Paoli and Greenfield (2013) and other scholars identify problems of scope, scale, and commensurability and point to issues of non-trivial data deficiencies. The challenges are all-the-more daunting if addressing harm as a concern that spans a range of interests, not all of which are amenable to monetization or indexation. Only recently have we developed a framework (Greenfield and Paoli, 2013) to assess the harms of crime that, in reaching out across disciplines, addresses many of those challenges. But that framework is not without its limitations and is still in its formative stages.

As for policy makers, we offer three, mutually reinforcing explanations.

First, the literature suggests that decisions about the criminalization and prioritization of illicit activities in crime control are heavily influenced by moral considerations and, sometimes, feelings of outright "disgust" (Nussbaum, 2004). Emile Durkheim ([1893], 1997) another father of contemporary criminology, was the first to point out that societies criminalize those activities that conflict with the "collective conscience." We also know (Cohen, [1972] 2002) that the norms and values that make up the collective conscience can be manipulated by shrewd politicians or moral entrepreneurs to engender "moral panics": exaggerated, hostile reactions to certain sets of "folk devils" and their deviant activities, which often engender "deviancy amplification" (Wilkins, 1964). Other scholars suggest that crime-control policy has increasingly become a means to placate the growing anxieties of the middle classes at living in the ever more uncertain and insecure world of the late modernity (e.g., Bauman, 2000; Young, 2007). On that basis, policy makers might have little need for 
the consideration of the incidence, severity, and causes of the harms of crime or for the appropriateness or effectiveness of the measures implemented.

Second, policy makers must also be responsive to emergencies, such as terrorist attacks and shocking criminal events, and cannot wait around for the results of multiannual academic studies or long-term policy evaluations.

Third, insomuch as policy makers have sought an evidentiary base for making decisions about criminalization or the prioritization of illicit activities in crime control, the lack of a practical approach to gathering and evaluating that evidence, either quickly or over a longer period, might, in turn, have discouraged them.

Admittedly, the logic is a little circular, but a lack of enthusiasm for alternative approaches, either based in a historical or philosophical perspective, coupled with the inherent challenges of developing an alternative approach, might have begot a lack of tools, which, in turn reinforced the lack of interest.

Why then the recent interest in harm? Perhaps it just comes down to a confluence of societal trends and events. In an era of fiscal prudence, if not crisis, the term "evidence-based" has made its way into policy-making and gained traction across policy arenas - some might argue to the point of rampant overuse. Although a harmbased approach is only one possible response, we believe it is a natural fit for crime control and suggest at least two reasons for cultivating it, below.

\section{The Case for Harm Assessment}

In this section, we consider the ways in which harm assessment can serve both criminology and crime-control policy.

With regard to criminology, assessing and comparing the harms of different criminal activities can provide a means to better address the criticisms raised against traditional criminology "from the left and the right" (Laub, 2004: 8).

From the 1960s onward, "left-wing" criminologists have stressed the constructed nature of the concept of crime, warned against any easy equivalence between natural and social sciences, and claimed that our criminal justice systems are too skewed on the repression of ordinary criminals whereas more harmful activities of corporations, governments, and their representatives are not criminalized or prosecuted effectively. By applying the harm assessment framework or other such methodologies, criminologists can further contribute to the "deconstruction" of the concept of crime. In fact they can establish the different harms of different criminalized-and legal-activities and the varying extent to which these harms are due to specific policy choices and enforcement practices. Thus, they might be better able to contribute with real evidence to the normative debate about what ought to be or not to be criminalized and prioritized in crime control.

Through the same exercise, criminologists can also address the old criticism of many "right-wing" criminologists that the search of the root causes of crime is irrelevant to 
policy. In fact, pointing out, as we have done in our first analyses (Paoli, Greenfield and Zoutendijk, 2013; Paoli, Decorte, Kersten, 2015), that most harms associated with, say, cocaine trafficking or cannabis production in Belgium are caused by policy or enforcement choices, we can suggest an immediate starting point for policy makers, seeking to alleviate the harms associated with crime.

With regard to crime-control policy, harm assessment can contribute to the establishment of priorities in crime-control policy, the development of more costeffective policy, and, in the long term, improvements in the accountability of policy. Over the past thirty years, criminology has created an impressive body of evidence on "what works" and "what doesn't work" in crime prevention and control (e.g., Sherman, et al. 1998; MacKenzie, 2006; Welsh and Farrington, 2006); but, it has had less success in providing policy makers with a firm analytical foundation for deciding whether a criminal activity merits prioritization or, even more fundamentally, criminalization. Criminology has focused on evaluating specific policy programs and interventions, rather than the objectives, of crime control. We recognize that decisions about criminalization and prioritization in crime control cannot rest solely on science, but we maintain that informing the decision-making process with a systematic, empirical analysis of the harms of crime can result in policy that employs resources more cost-effectively and with greater legitimacy (see also Ashworth, 2006).

Drawing from Greenfield and Paoli (2013: 870-871), we delineate the roles that a systematic, empirical assessment of the harms of crime can serve in policy analysis and that, separately and in combination, would support the establishment of priorities and the pursuit of effectiveness and accountability.

First, the comparison of harms across different types of criminal activities can provide initial evidence for setting strategic, long-term priorities for the criminal justice system. One might, for example, be able to rank activities according to their harmfulness and, without disqualifying "low hanging fruit," address those posing the greatest threats to bearers first. More harmful activities might merit greater attention than less harmful activities, but, as we address below, decisions about the implementation of policy measures - and the allocation of resource to them-should involve consideration of the cost side of the equation.

Second, the identification of especially "harmful" perpetrators can help law enforcement agencies set their short- and mid-term operational and tactical priorities. The assessment process might, for example, reveal that certain types of perpetrators, distinguished by location, criminal affiliations, or other characteristics, disproportionally engage in particularly harmful activities.

Third, a harm-based approach can be used to assess and compare the impact, including the unintended consequences and distributional effects, of different types of policy regimes or of particular policy measures. The assessment, which might entail a detailed analysis or a well-structured thought exercise, would require repetition to compare the effects of changes in assumptions about the policies or 
measures in play. A comparison of the status quo with an alternative policy scenario, be it "no policy" or a newly proposed policy, could be used to support a "notional" cost-benefit analysis of the status quo in relation to the alternative. However, a full comparison across options, even if only notional, would necessitate consideration of the implementation costs of each of the alternatives. Absent consideration of those costs, one might inadvertently allocate resources at a net "loss."

Fourth, a harm-based approach, particularly if it entails the identification of the individual and institutional bearers of harm, can provide a more encompassing basis for restorative justice interventions and enable the expansion of restorative justice programs beyond their current focus on interpersonal crimes.

Fifth, an assessment of the severity of the harms of a crime, irrespective of the incidence, can provide an empirical benchmark for gauging the harmfulness component of the seriousness of offences and, thereby, for reviewing existing sentences and sentencing guidelines.

Sixth and most fundamentally, one might use a harm-based approach to consider whether specific activities warrant criminalization in the first place. In effect, one would use the approach to ask whether an activity, criminal or otherwise, is sufficiently harmful to be called out as "criminal." From this empirical perspective, some activities that have been deemed criminal might not seem to deserve that status and other activities that have been regulated by administrative or civil law might look more deserving (see Ashworth, 2006: 53-4, 46-7). If the approach were expanded to account for the benefits of activities with "full accounting" (Greenfield and Paoli, 2012), it could be applied to any repeated activity that, even if legitimate, is suspected of generating harms (e.g. tobacco production and trade).

Our appraisals of both the state-of-the-art in harm assessment and the policy landscape support Ashworth's (2006: 39) conclusion that "the task of assessing the seriousness of the offence is... as complex and problematic as it is unavoidable and fundamental." Obviously, decisions what ought or not ought to be criminalized, which penalties should be set out and imposed, and which criminal activities, harms, and bearers deserve prioritization in crime control are inherently normative.

Nonetheless, in times of growing or at least persistent anxieties and shrinking public resources, these decisions can become more "cost-effective" and accountable, if they are informed by the evidence that criminologists and other social scientists can provide. Insomuch as crime control is an arena in which governments purposefully impose harm on their citizens and others, by meting out punishment to offenders, policy makers and law-enforcement officials might be said to have a special responsibility to conduct a rough check, if not a thorough assessment of the net consequences of their strategies and tactics. And, as argued above, it is also in criminology's interest to embrace this new and challenging task.

\section{Reference list}


Ashworth, A. (2006). Principles of Criminal Law. Oxford: Oxford University Press.

Bauman, Z. (2000). Social Uses of Law and Order. In D. Garland and R. Sparks (eds).

Criminology \& Social Theory, pp. 23-45. Oxford: Oxford University Press.

Bottoms, A. (2008). The Relationship between Theory and Empirical Observations in Criminology. In R.D. King and E. Wincup (eds). Doing Research on Crime and Justice, pp. 75-116. Oxford: Oxford University Press.

Caulkins, J.P. and Reuter, P. (1997). Settings Goals for Drug Policy: Harm Reduction or Use Reduction? Addiction 92(9): 1143-1150.

Christie, N. (2000). Crime Control as Industry: Towards GULAGs, Western Style? London: Routledge.

Clarke, R.V. (2004). Technology, Criminology and Crime Science. European Journal on Criminal Policy and Research 10(1): 55-63.

---- (2012). Opportunity Makes the Thief. Really? And So What? Crime Science 2012, 1(3): 19.

Clarkson, C., Cretney, A., Davis, G., and Shepherd, J.P. (1994). Assaults: The Relationship between Seriousness, Criminalisation and Punishment. Criminal Law Review January: 4-20.

Clear, T.R. (1994). Harm in American Penology: Offenders, Victims and Their Communities. Albany: SUNY Press.

----. (2007). Imprisoning Communities: How Mass Incarceration Makes Disadvantaged Neighborhoods Worse. New York: Oxford University Press

Cohen L.E. and Felson M. (1979). Social Change and Crime Rate Trends: A Routine Activity Approach. American Sociological Review 44: 588-608.

Cohen, S. (1988). Criminology. In Against Criminology. New Brunswick: Transaction: 3-7.

Cohen, S. ([1972] 2002). Folk Devils and Moral Panics: The Creation of the Mods and Rockers. $3^{\text {rd }}$ ed. London: Routledge.

Council of the European Union. (2010). The Stockholm Programme - An Open and Secure Europe Serving and Protecting Citizens. Official Journal of the European Union C 115: 138.

Cullen, F.T., Agnew, R. and Wilcox, P. (2013) Criminological Theory: Past to Present: Essential Readings. New York: Oxford University Press.

Dorn, N. and van de Bunt, H. (2010). Bad Thoughts: Towards an Organised Crime Harm Assessment and Prioritation System. Rotterdam: Erasmus University.

Durkheim, E. ([1893], 1997). The Division of Labor in Society. New York: Free Press.

EMCDDA, European Monitoring Centre for Drugs and Drug Addiction. (2012). 2012 Annual Report on the State of the Drugs Problem in Europe. Luxembourg: Publications Office of the European Union.

Eser, A. (1966). The Principle of Harm in the Concept of Crime: A Comparative Analysis of Criminal Protected Legal Interests. Duquesne University Law Review 4: 345-417.

Europol. (2013). SOCTA 2013: EU Serious and Organised Crime Threat Assessment. 'sGravenzande: Deventer.

Fijnaut, C. (2014). Criminologie en strafrechtsbedeling. Antwerpen: Intersentia.

Garland, D. (2002). Of Crimes and Criminals: the Development of Criminology in Britain. In: M. Maguire, R. Morgan, and R. Reiner (eds). The Oxford Handbook of Criminology, pp. 7-50. 3rd ed. Oxford: Oxford University Press.

Greenfield, V.A. and Camm, F. (2005). Risk management and performance in the Balkans support contract. St. Monica: Rand. 
Greenfield, V.A. and Paoli, L. (2012). If Supply-Oriented Drug Policy is Broken, Can "Harm Reduction" Help Fix It? International Journal of Drug Policy, 23(1): 6-15.

Hillyard, P. and Tombs, S. (2004). Beyond Criminology? In P. Hillyard, C. Pantazis, S. Tombs, and D. Gordon (eds), Beyond Criminology: Taking Harm Seriously, pp. 10-29 London: Pluto Press.

Hirschi, T. (1969). Causes of Delinquency. Berkeley: University of California Press.

Kopp, P. and Besson, F. (2009). A Methodology to Measure the Impact of Organised Crime Activities at the EU Level. In E. Savona (ed.), Organised Crime in the EU, pp. 301-320. Rotterdam: Erasmus University.

Laub, J. (2004). The Life Course of Criminology in the United States: the American Society of Criminology 2003 Presidential Address. Criminology, 42(1) 1-26.

Levi, M. and Burrows, J. (2008). Measuring the Impact of Fraud in the UK. British Journal of Criminology 48: 293-318.

Levi, M., Innes, M., Reuter, P. and Gundu, R.V. (2013). The Economic, Financial and Social Impacts of Organized Crime in the European Union. Report requested by the European Parliament. Brussels: European Union.

Lippke, R.L. 2012. Anchoring the Sentencing Scale: A Modest Proposal. Theoretical Criminology 16(4): 463-480.

Lombroso, Cesare. 1876. L'uomo delinquente studiato in rapporto alla antropologia, alla medecina legale ed alle discipline carcerarie. Milano: Hoepli.

MacCoun, R.J., Reuter, P. and Schelling, T. 1996. Assessing Alternative Drug Control Regimes. Journal of Policy Analysis \& Management 15: 1-23.

MacKenzie, D.L. 2006. What Works in Corrections? Reducing the Criminal Activities of Offenders and Delinquents. Cambridge: Cambridge University Press.

Maltz, M.D. 1990. Measuring the Effectiveness of Organized Crime Control Efforts. Chicago: OICJ.

Mayhew, P.M., Clarke, R.V., Sturman, A. and Hough, J.M. 1976. Crime as Opportunity. Home Office Research Study, No 34. H.M.S.O, London.

Merton, R.K. 1938. Social Structure and Anomie. American Sociological Review 3(5): 672-682.

Mill, J.S. ([1859], 1977). On Liberty, in J.M. Robson, (ed.) Essays on Ethics, Religion and Society, vol. XVIII, pp. 213-309. Toronto: University of Toronto.

Newcombe, R. 1992. The Reduction of Drug-Related Harm: A Conceptual Framework for Theory, Practice, and Research. In P. O'Hare et al. (eds) The Reduction of Drug-Related Harm, pp. 1-14. London: Routledge.

Newburn, T. 2007. Criminology. London: Routledge, 2nd ed.

Nussbaum, M. 2004. No Offense; Mere Disgust Should Not Constitute a Cause of Action. The American Lawyer. October 1 . Online available at: http://www.law.uchicago.edu/news/nussbaum100104

Paoli, L. 2014. How to Tackle (Organized) Crime in Europe? The EU Policy Cycle on Serious and Organized Crime and the New Emphasis on Harm. European Journal of Crime, Criminal Law and Criminal Justice 22: 1-12.

Paoli, L. Decorte, T. and Kersten, L. (2015). Assessing the Harms of Cannabis Cultivation in Belgium. International Journal of Drug Policy, 26(3): 277-289.

Paoli, L. and Kersten, L. 2013. The Harms of Cocaine Trafficking in the Netherlands. Paper presented to the conference "New Methodological Tools for Policy and Program Evaluation," Lisbon, February 8.

Paoli, L. and Greenfield, V.A. 2013. Harm of Crime: A Neglected Concept. European Journal of Crime, Criminal Law \& Criminal Justice 21: 359-77. 
Paoli, L., Greenfield, V.A., Zoutendijk, A. 2013. The Harm of Cocaine Trafficking. Applying a New Framework for Assessment, Journal of Drug Issues 43: 407-436.

Rothe, D. and Kauzlarich, D. (2014). Towards a Victimology of State Crime. London: Routledge.

Rubin, E.L. (1999). Introduction: Minimizing Harm as a Solution to the Crime Policy Conundrum. In E.L. Rubin (ed.) Minimizing Harm: A New Crime Policy for Modern America, pp. 1-33. Boulder: Westview.

Sampson, R.J. (2013). Great American City: Chicago and the Enduring Neighbourhood Effect. Chicago: University of Chicago Press.

Shepherd, J., (1997). Violence: the Relation between Seriousness of Injury and Outcome in the Criminal Justice System, Journal of Accident and Emergency Medicine 14: 204-208.

Sherman, L.W. (2007). The Power Few: Experimental Criminology and the Reduction of Harm. The 2006 Joan McCord Prize Lecture. Journal of Experimental Criminology 3: 299-321.

Sherman, L.W., Gartin, P.R., and Buerger, M.E. (1989). Hot Spots of Predatory Crime: Routine Activities and the Criminology of Place. Criminology 27: 27-55.

Sherman, L.W., Gottfredson, D., MacKenzie, D., Eck, J., Reuter, P. and Bushway, S. 1998. Preventing Crime: What Works, What Doesn't, What's Promising A Report to the United States Congress.

Sherman, L.W., Neyroud, P. and Neyroud, E.C. (2014). The Cambridge Crime Harm Index (CHI). Draft paper.Shoham, S.G., Knepper, P., and Kett, M. (2010). International Handbook of Victimology. Boca Raton: CRC Press.

SOCA, Serious Organised Crime Agency. (2008). The United Kingdom Threat Assessment of Serious Organised Crime 2008/9.

Sparrow, M. (2008). The Character of Harms. Operational Challenges in Control. Cambridge: Cambridge University Press.

TFEU, Consolidated Version of the Treaty on the Functioning of the European Union. Official Journal of the European Union, C 115 (9 May 2008). 47-199.

Tusikov, N. (2012). Measuring Organised Crime-Related Harms. Crime, Law and Social Change 57(1): 99-115.

UK Drug Policy Commission. (2009). Refocusing Drug-Related Law Enforcement to Address Harms. London.

Vander Beken, T., Paoli, L., Zoutendijk, A., and Klima, N. (2012). Het inschatten van de gevaarlijkheid van georganiseerde criminaliteit. Gent: Academia Press.

Von Hirsch, A. and Jareborg, N. (1991). Gauging Criminal Harms: A Living Standard Analysis. Oxford Journal of Legal Studies 11(1): 1-38.

Von Hirsch, A. 2009. Proportionate Sentences: A Desert Perspective. In von Hirsch A, Ashworth A and Roberts J (eds) Principled Sentencing. Readings on Theory and Policy: 115-125.

Walklate, S. (ed.) (2007). Handbook of Victims and Victimology. Cullompton: Willan.

Wacquant, L. (2009). Punishing the Poor. The Neoliberal Government of Social Insecurity. Durham: Duke University Press.

Welsh, B.C. and Farrington, D.P. (2006). Preventing Crime: What Works for Children, Offenders, Victims, and Places. New York: Springer.

White, R. (ed.) (2011). Global Environmental Harm: Criminological Perspectives. Portland: Willan.

Wilkins, L.T. (ed.) (2001). Social Deviance: Social Policy, Action, and Research. London: Tavistock. 
Wikstrom, P.O. (2008). In Search of Causes and Explanations of Crime. In R.D. King and E. Wincup, (eds). Doing Research on Crime and Justice, pp. 117-137. Oxford: Oxford University Press.

Wikstrom, P.O., Oberwittler, D., Treiber, K., and Hardie, B. (2012). Breaking Rules: The Social and Situational Dynamics of Young People's Urban Crime. Oxford: Oxford University Press.

Yar, M. (2012). Critical Criminology, Critical Theory and Social Harm. In S. Hall and S. Winlow (eds). New Directions in Criminological Theory, pp. 52-65. Oxon: Routledge.

Young J. (2007). The Vertigo of Late Modernity. London: Sage. 